\title{
Trace volatile metals and noble gases in deep sampling at Theistareykir geothermal field, NE Iceland: it is not only about volcanic arcs
}

\author{
MARION SABY ${ }^{1}$, VINCENT VAN HINSBERG ${ }^{2}$, PROF. \\ DANIELE L. PINTI, PHD ${ }^{1}$, KIM BERLO ${ }^{2}$, OCÉANE \\ ROCHER $^{3}$, ÁSGERĐUR K. SIGURĐARDÓTTIR ${ }^{4}$, BJARNI \\ GAUTASON $^{5}$ AND BROWN KEVIN $^{6}$ \\ ${ }^{1}$ Université du Québec à Montréal \\ ${ }^{2}$ McGill University \\ ${ }^{3}$ Université de Strasbourg \\ ${ }^{4}$ Landsvirkjun \\ 5 ÍSOR Iceland GeoSurvey \\ ${ }^{6}$ GEOKEM Consultancy \\ Presenting Author: marion.saby23@gmail.com
}

The source of metals in magmatic-hydrothermal systems is a matter of debate with opinions divided between those who favor magma degassing as the primary source, and those who see a principal role for water-rock interaction and metal leaching. Noble gases have the potential to provide key insights in this debate, because the elemental and isotopic signatures of the noble gases strongly differentiate these sources. Here, we present results of a study where we use correlations between noble gases and metals in deep geothermal fluids sampled down-well to elucidate metal sourcing. Samples are from the newly developed Theistareykir geothermal field of NE Iceland, as well as the adjacent Krafla system. Noble gas samples were collected at the well heads and analyzed for $\mathrm{He}, \mathrm{Ne}, \mathrm{Ar}, \mathrm{Kr}$ and $\mathrm{Xe}$ concentrations, and their isotopes. Fluid samples were collected at the well heads, and in two wells at depths down to $1600 \mathrm{~m}$ using a down-hole fluid sampler. The noble gases indicate significant variations in fluid sources, including variations in magmatic gas input, over the geothermal field that correlate with selected metals. Thallium, in particular shows a strong correlation with ${ }^{3} \mathrm{He}$. In comparison with their basaltic host rocks the deep fluids are enriched in alkali $(\mathrm{Li}, \mathrm{Na}, \mathrm{K})$ and volatile metals ( $\mathrm{Ag}, \mathrm{Cd}, \mathrm{Sb}, \mathrm{Tl}, \mathrm{Pb}, \mathrm{As}, \mathrm{Hg}$ ) and are depleted in refractory $(\mathrm{Ti}, \mathrm{V}, \mathrm{Cr})$ and rare earth elements. We therefore preliminarily conclude that the volatile metals in these deep fluids have a predominantly magmatic source. 